\title{
LA DEVOCIÓN A LA MADRE SANTÍSIMA DE LA LUZ: UN ASPECTO DE LA REPRESIÓN DEL JESUITISMO EN LA ESPAÑA DE CARLOS III
}

\author{
Enrique GIMÉNEZ LÓPEZ
}

Universidad de Alicante

Un capitulo importante de la represión del jesuitismo y de sus seguidores concernía a "la mala doctrina", según se calificaba genéricamente al probabilismo que -como afirmaban los enemigos de la Compañía de Jesús- abría las puertas a la relajación, al escepticismo y a la simulación. De este ampísimo capítulo, un apartado poco conocido de la casuística represora, extraordinariamente activa tras la expulsión y ejecutada sin contemplaciones, es la relativa a devociones que se consideraban alentadas por la orden ignaciana y que estaban destinadas a mantener vivo entre sus afectos, los calificados "terciarios", el espíritu de cuerpo y la homogeneidad sin fisuras de la Compañía, fundamento -se creía- de su gran poder y capacidad de influencia, y en lo que Campomanes fijaba su fanatismo al ser "máquinas indefectibles de la voluntad de los Superiores"1. Además del culto al Corazón de Jesús, motivo de agrias polémicas que no vamos a tratar aquí ${ }^{2}$, tuvo una particular relevancia la devoción a la Madre Santísima de la Luz. Iniciada en Sicilia en el primer cuarto del siglo XVIII, tras unas supuestas revelaciones de la Virgen María a una señora de la isla ${ }^{3}$, su fervor fue alentado por los jesuitas italianos en los años treinta y cuarenta y difundida en España y América durante el reinado de Fernando VI y primeros años del de Carlos III po miembros de la propia Compañía, y con afán de contraponerla a aquellas otras Luces que intentaba propagar la nueva filosofia. Deciarada por la Compañia protectora de las Misiones, en 1756, el jesuita Diego de Rivera, en el sermón pronunciado en la iglesia del Colegio Imperial de Madrid con motivo de la inaguración de un altar consagrado a la Madre Santisima de la Luz. señalaba que "en estos últimos tiempos, en que la Fe se halla tan combatida de las modernas Sectas, y en que no, sin dolor, vemos que aún en muchos católicos, o por el demasiado comercio con los Novatores, o con sus libros, o por un orgullo vano de ciertos genios, dedicados a novedades, está casi extinguida la 
piedad, y agonizando la Fe, se coloca la Madre Santisima de la Luz en aquel Altar"4, es decir, la luz auténtica, la que disipa las tinieblas de la noche, frente a la luz engañosa de la razón ilustrada. Es, por ello, frecuente en los textos divulgadores del culto de la Madre Santísima de la Luz las referencias al texto mariológico del Apocalipsis: "una gran señal apareció en el cielo: una Mujer. vestida del sol, con la luna bajo sus pies..." $(12,1)$; y al Dragón, que se halla presente como uno de los elementos básicos en la inoconografía de la Madre Santísima de la Luz: " $Y$ apareció otra señal en el cielo: un gran Dragón rojo, con siete cabezas y diez cuernos..." $(12,3)$. Tobar la califica de "sol" que ilumina a los justos, de "aurora" que alumbra a los penitentes y, finalmente, de "luna" que da claridad a los pecadores'. Asi, ella es el prototipo de la Iglesia, perseguida por los agentes del mal, por el dragon infernal revestido con los adornos de la nueva fillosofía.

La primera manifestación de este culto en España se sitúa en el Colegio Imperial de Madrid, donde se erigió una Congregación con el nombre de "Madre Santísima de la Luz", redactándose sus Constituciones en agosto de 1754. y se levantó un altar en $1756^{\circ}$. Con antelación, en Méjico, el jesuita Lucas Rincón había publicado en 1737, y con el título "Antídoto contra todo mal", la traducción de la obra italiana, también obra de jesuitas, "La devoción de Maria. Madre Santíssima de la Luz", impresa en dos tomos en Palermo entre los años 1733 y 1734. La finalidad estatutaria de esta primera Congregación madrileña era "saprender, practicar $y$ procurar que otros aprendan y practiquen la verdadera y sólida devoción a la Reina del Cielo, manifestándose a un tiempo la Virgen Maria en su imagen como Madre de la Luz", además de organizar ejercicio espirituales "según las reglas y método que prescribió en su libro de oro el Santo Patriarca San Ignacio", a lo que hace mención José Simón Diaz, en su historia del Colegio Imperial, reimprimiendo para ese fin en 1763. y a expensas de la propia congregación, la Práctica de los Ejercicios espirituales de Nuestro Padre San Ignacio, del P. Sebastián Izquierdo, con adiciones específicas para los congregantes ${ }^{7}$, además de celebrar una fiesta anual el miércoles inmediato antes de la Pascua del Espíritu Santo, el rezo de cinco rosarios por las calles y un día de retiro mensual. La congregación madrileña quedó agregada, por patente de 23 de diciembre de 1755 otorgada por el Prepósito General Luis Centurión, a la Congregación de la Anunciata existente en el Colegio Romano de la Compañía desde 1584 .

Con anterioridad, en 1751, había sido publicado en Madrid el libro del teólogo José de Tobar titulado Invocación de Nuestra Señora con el título de Madre Santísima de la $L u z^{8}$ en el que se explicaba la aparición de dicha Virgen, y se hacía una larga reseña de algunos de los "prodigios debidos a los ruegos de la Madre Santíssima" y de sus numerosas apariciones, en ocasiones acompañada por el propio San Ignacio, o actuando éste por delegación expresa de la Virgen ${ }^{10}$. Era sabido que, para una rápida difusión del culto, era imprescindible dotar a la imagen de la maxima capacidad milagrera posible. Según Tobar ${ }^{1 i}$, "las gracias, que obran las Santas Imágenes de la Madre de la Luz son innumerables, no pueden contarse, son 
infinitas". Su libro se convirtió en el principal exponente de ỉa propaganda jesuítica a favor del cuito, y para mayor difusión fue reimpreso en Zaragoza en $1757^{i 2}$ con un anexo que incluía una carta del jesuita italiano Marcelo Tipa donde explicaba el origen de la devoción en Sicilia.

Durante la primera mitad de los años sesenta la devoción se extendió a otros lugares, cuidando de no entrar en competencia con el culto a la Inmaculada, con gran predicamento en los paises católicos mediterráneos, y tratando de identificar luz con inmaculada. Una supuesta aparición del Arcángel San Gabriel había "alentado a creer que tanto monta Madre Inmaculada como Madre de la Luz" ${ }^{\prime 3}$, y no olvidemos que el saludo de Gabriel a María - ave gratia plena - había sido tomado en su dimensión máxima, implicando que en el tiempo de la Anunciación. María estaba llena de gracia, sin pecado, y que esta lectura, que tanto irritaba a los protestantes, habia sido abanderada por la propia Compañía de Jesús desde el instante mismo de su fundación en 1540, hasta lograr acabar con las reticencias y objeciones que los dominicos habian expresado hasta el siglo XVII a las tesis inmaculistas.

El procedimiento seguido para difundir el culto respondía siempre al mismo patrón, que podemos conocer siguiendo el ejemplo palentino, descrito con detalle en la documentación vaticana ${ }^{14}$. En Palencia se inaguró en 1761 un altar a la Madre Santísima de la Luz con música y sermón, en el que el orador sagrado pidió que todos se encomendaran a dicha Virgen, repartiéndose gratuitamente novenarios, medallas y estampas traidas de Madrid. El promotor del culto en Palencia era el matrimonio formado por Manuel Agustín Ruiz y Josefa Prieto de Vega, congregantes en la primera congregación fundada en el Colegio Imperial, ya referida's. Un año después se efectuó un acto similar, para el que se logró reunir un mayor número de asistentes. Los promotores encargaron una pintura de la Madre Santísima de la Luz, cuya iconografia estaba tipificada y que más tarde comentaremos, que colocaron junto al balcón de su casa con una lámpara permanentemente encendida, y a la que "todos acudian incesantemente, de día y de noche, a ponerse debajo de su amparo", llevando numerosos ex-votos por los favores recibidos. El paso siguiente era solicitar al obispo de la diocesis permiso para colocar la imagen en un templo, si bien otra imagen, de mayores dimensiones y pintada en Roma, fue colocada en uno de los altares del Colegio que los Jesuitas poseían en Palencia ${ }^{10}$.

En otros lugares proliferaron en esas mismas fechas imágenes de la Madre Santísima de la Luz: en Zaragoza fueron detectadas varias, que eran veneradas pública y privadamente, en particular en el Colegio del Padre Eterno o Casa de Probación que la Compañía poseía en la ciudad; también en el Colegio de Belén de Barcelona se instaló en una de sus capillas un lienzo con dicha imagen, al igual que en el convento de las monjas de la Enseñanza de Lérida ${ }^{17}$, al que más adelante nos referiremos con detalle; en la parroquia de San Millán de Madrid, a través de la Congregación de San Judas Tadeo, y en los conventos de monjas del Sacramento y Don Juan de Alarcón; en la villa de Capella, en Aragón, donde se erigió una 
Congregación en diciembre de 1762, con su correspondiente altar; en el lugar de San Pelayo, en la diócesis de Palencia, también se fundó en 1763 una Congregación denominada "de la Santísima Madre", etc. La creación de congregaciones y el levantamiento de altares venía acompañada de la difusión de una abundantísima propaganda impresa en forma de estampas, novenarios y opúsculos de mayor o menor volumen sobre los beneficios que se obtenían de aquella devoción. El jesuita Pedro Echavarri había publicado en Madrid en 1757 una Novena a María Santísima Madre de la Luz, procurando disipar posibles dudas sobre su culto, incluyendo en el texto un Decreto de 19 de mayo de 1763 dado por el Arzopispado de Toledo concediendo 100 dias de indulgencia a todos los que rezasen un Ave María o una Salve ante cualquier lienzo o estampa de la Santísima Madre, o un supuesto Decreto expedido el 15 de enero de 1758 por Benedicto XIV que otorgaba 200 dias de indulgencias por cada vez que se rezase una letanía ante la imagen venerada en el Colegio de los jesuitas de Zaragoza. Se imprimió también la letra apostólica de Clemente XIII de 3 de mayo de 1763 concediendo 200 dias de indulgencias a quien rezara ante la imagen del Colegio de Belén de Barcelona.

Tal avalancha de impresos y los numerosos beneficios e indulgencias que recaian sobre los fieles devotos de la nueva imagen, pretendía contrarrestar a quienes se manifestaron contrarios a la difusión de su culto. Según estos últimos, la Madre Santísima de la Luz había sido prohibida en 1742 por la Congregación de Ritos, y así había sido comunicado al obispo de Siracusa, en Sicilia, por un decreto de 27 de enero de dicho año, al que hacía expresa referencia Benedicto XIV en el libro cuarto de su obra De Beatificatione. Además, los primeros opúsculos, de autor jesuita, editados en 1733-1734, 1738 y 1739 habian sido incluidos en el Índice en mayo de 1745, y también se consideraba prohibido por la Sagrada Congregación del Índice, por decreto de 8 de mayo de 1761, el libro de José Tobar al que hemos hecho referencia con anterioridad. La propia Compañía de Jesús denunciaba las críticas a la devoción a la Madre Santísima de la Luz como un ataque más de los que recibia la Iglesia de quienes, desde dentro de ella, actuaban como quinta columna de los impios a la búsqueda de su aniquilación. El P. Rivera, al referirse a los que deseaban que se limitasen los excesos del culto mariano, los acusaba de querer "ceñir tan estrecha y escrupulosamente el culto a la Santisima Virgen" para asi "introducir el veneno de sus errores". Recriminaba, en tono de denuncia, que "ha llegado su delirio a tanto en estos tiempos, que apenas hay Himno, Antifona u Oración de las que usa nuestra Madre la Iglesia, para saludar y alabar a nuestra gran Reina, que no la hayan querido reformar, excediendo en esto algunos Novatores modernos, auin a sus mismos pestilentes maestros"18.

Las razones de la polémica se encuentraban, sobre todo, en la propia representación iconográfica de la Madre Santísima de la Luz. Segun se señalaba en el libro de José de Tobar, la imagen respondía exactamente a lo narrado por la testigo de la aparición en Sicilia, pues la propia Virgen, que "despedia de su luz celestial semblante un torrente de luz tan viva, y tan copiosa, que en su comparación 
huviera parecido una lucerna del campo el mismo Sol"19, le habia ordenado que su representación se sujetara estrictamente a lo contemplado en la milagrosa aparición: "Vete, pues, ahora, añadió la Virgen, y como me has visto, asi puntualmente quiero ser expresada en el lienzo, y debajo de esta divisa, invocada con el nombre de Madre Santísima de Luz". En los textos divulgadores del culto a la Madre Santisima de la Luz se afirmaba que la Virgen misma habia supervisado la fidelidad de su representación iconográfica, hasta el punto de "ir invisiblemente governando la idea y mano del pintor, para que saliese, como de hecho salió, la copia tan parecida, que no ha sido posible hasta ahora formarse retrato que perfectamente se parezca a este Celestial original, por más que lo hayan intentado los más insignes pintores, $y$ aún su mismo autor que de su mano la pintó" ${ }^{\prime 2}$. La virgen, que vestía túnica blanca con faja esmaltada en la cintura y manto azul sobre los hombros ${ }^{2 i}$, ceñia corona imperial y sostenía en su brazo izquierdo al niño Jesús, "en ademán de sacar del horrible abysmo del Infierno una alma pecadora, y de mantenerla estrechamente asida por la mano, y suspensa, para que no bolviese a caer"'22. La icongrafía al uso solía estar acompañada de aditamentos jesuíticos complementarios. Así, por ejemplo, las figuras de San Ignacio y San Francisco de Borja en el altar del convento de Lérida, o "un angel con un azafate de corazones en las manos en ademán de ofrecérselos" en el lado izquierdo de la imagen existente en Albarracín, tal y como la describió el obispo de aquella diócesis en su edicto prohibitivo de $1770^{23}$.

Iconografía básica y simbología jesuítica complementaria estaban, en opinión, de los enemigos de la Compañía, estrechamente vinculadas. El hecho de que la Virgen se representara extrayendo del infierno - o evitando su caída ${ }^{24}$ - el alma de un condenado no sólo transgredía la teología de la intercesión de la Virgen, que sostiene, de manera estricta, que María no puede otorgar favores por sí misma, sino que sólo intercede ante su hijo que, como Dios, es la única fuente de salvación, sino que violaba un dogma fundamental de la religión cristiana, subrayada por San Agustín: que las penas del infierno son eternas, lo que se consideraba, por los enemigos del laxismo jesuítico, como una prueba irrefutable y gravísima de los extraordinarios peligros a que conducía la relajación propia de la moral de la Compañía. Sin embargo desde esta posición rigorista no se atendía a que, más allá de la regla moral estricta, en infinidad de relatos milagrosos, de origen más o menos popular, la Virgen usurpaba los privilegios únicos de Cristo, apareciendo con soberania autónoma, y que ese papel habia sido destacado, en los límites de lo técnicamente ortodoxo, en los momentos culminantes de lucha de la Contrarreforma contra los reformadores protestantes por la propia Compañía de Jesús ${ }^{25}$. El obispo Francisco Armañá, siendo prelado de Lugo, dedicó en 1770 una de sus pastorales, incluida más tarde en el tomo I de las que en 1794 se publicaron impresas, al tema de la Madre Santísima de la Luz, y supo poner el acento en esa cuestión central: "La sencillez del vulgo, siempre propenso a creer grandes prodigios, y más cuando favorecen al amor propio, fácilmente creería que por el amparo de la Madre de Dios no sólo se libran las almas de los peligros de este mundo, sino también de las penas del infierno"2t. Mediante esa moral acomodaticia, favorecedora del "amor propio", 
los jesuitas lograban, a criterio del prelado, un gran numero de seguidores: "el pecador se abandonaria con más desenfreno a vicios, vanamente confiado de que aún quando le hallare la muerte en el infeliz estado de pecado mortal, podria salvarle el patrocinio de la Virgen habiéndola venerado con alguna devoción ligera"2?.

La preocupación que llevó al Consejo Extraordinario a tomar medidas concretas y contundentes contra la devoción a la Madre Santísima de la Luz tuvo su origen en el incidente acaecido en Lérida en 1768 que puso en evidencia cómo, en torno a su culto y con la permisibilidad del obispo, se agrupaban seglares y religiosos dispuestos a mantener vivo el recuerdo y la doctrina de la Compañia expulsa. El incidente leridano es también un exponente más de la lucha de escuelas que cobró, tras la expulsión, una nueva dimensión y un modo distinto de desarrollar viejos resentimientos ${ }^{28}$.

Antes de la expulsión, en 1766, el sacerdote Domingo Barri, párroco de la iglesia de Santa Maria Magdalena de Lérida, concurrió a una plaza de canonigo magistral de la catedral de Barcelona. Barri, que habia estudiado en Cervera, habia llegado a Lérida con la intención de impartir filosofia tomista en el Seminario, cuyo hermano, José Barri, era rector, lo que no pudo hacer por la abierta oposición de los jesuitas $^{29}$. Tampoco logró la plaza de Barcelona, cuyas oposiciones impugnó ya que, en su opinión, la elección del candidato correspondía al rey y no al cabildo barcelonés. Su tomismo militante, y su actitud en la oposición a magistral, le granjearon la enemistad de los jesuitas y su escuela y, por extensión, la del mismo obispo de Lérida Manuel Macías Pedrejón, afín, según Barri, a los de aquella corriente. Una situación ésta que había sido habitual en una España dividida en dos por un odium teologicum exacerbado. El tomista y más tarde arzobispo de Palmira, Félix Amat, fue testigo en su condición de seminarista en Barcelona, del encarnizado enfrentamiento entre el Seminario episcopal y los colegios de Cordelles y Belén que los jesuitas regentaban en la Ciudad Condal ${ }^{3 / .}$.

Pocos meses después de la expulsión, las hostilidades se desencadenaron en Lérida. Con el doble objetivo de granjearse apoyos en su pretensión de lograr una de las capellanias reales de San Isidro en Madrid, a la que pensaba concursar, pero también en la de poner en aprieto a sus enemigos projesuitas en Lérida, el párroco Barri redactó un escrito a Campomanes ${ }^{31}$, en el que ponía en conocimiento del fiscal su sospecha de la llegada a Lérida de un jesuita disfrazado. Para acrecentar el valor de su denuncia, manifestaba su temor a que se produjese un atentado contra el rey si aquél llegaba hasta la Corte - "...y quizás si semejante fanatismo sería para descargar el más sensible golpe en la respetable persona de muestro adorado Monarca"-, y la fuerza y apoyos con que contaban en Lérida los hijos de San Ignacio, en cuyos confesionarios se seguían impartiendo sus doctrinas y consejos.

La denuncia, tramitada al Consejo Extraordinario en octubre de 1767, no fue considerada al ser desmentida por el gobernador interino de Lérida Enrique de 
Wyels ${ }^{3 \hat{2}}$, que la juzgó fruto de la ambición del parroco Barri, deseoso de lograr méritos en su carrera a costa de hacerse eco de falsos rumores sobre la llegada a Cataluña de jesuitas huidos de Córcega disfrazados de mendigos: "todo su contexto es infundado y voluntario, nacido acaso del espiritu de ambición, que según el concepto comin tiene bastante dominio en este sujeto, y ha podido infundirle esperanzas de adelantar su crédito y su fortuna" ${ }^{\prime \prime 3}$.

Sin embargo, un segundo escrito de Domingo Barri a Campomanes, en forma de memorial, puso en marcha una investigación de mayor calado ${ }^{34}$. En él Barri denunciaba estar perseguido por los partidarios de la Compañía, de gran influencia sobre el obispo Macías Pedrejón. Su oposición a que se rindiera culto a una imagen de la Madre Santísima de la Luz, que se custodiaba en el convento de las monjas de la Enseñanza de Lérida, siguiendo la condena que ya efectuara en su momento Benedicto XIV, le habia valido la apertura de una sumaria y ser recluido en ei convento de capuchinos de la misma ciudad. Según Barri, la pintura que representaba a la virgen estaba custodiada por las imágenes de San Ignacio de Loyola y San Francisco de Borja, con gran profusión de simbología jesuítica a lo largo y ancho del retablo: corazones de Jesús y IHS, destacando, sobre todo, el libro abierto que sostenía San Ignacio con la leyenda escrita "Ad Maiorem Dei Gloriam" en una página y "Constitutiones Societatis Jesu" en la otra. Barri se había fugado del convento de los capuchinos "para tener libertad de defender su inocencia", y solicitaba la protección del Consejo.

El fiscal Moñino fue el encargado de instruir en el Consejo ei recurso de protección que solicitaba Barri. Su propuesta de 15 de marzo de 1769 se resumia en tres puntos, aceptados por el Consejo Extraordinario en sesion celebrada dos días después: en primer lugar, consideraba conveniente aceptar la solicitud de protección demandada; en segundo lugar, que el obispo leridano informase de la conducta del párroco y de los motivos del castigo que se le había impuesto; y por último, que el alcalde mayor de Lérida, Ramón de Lanes, efectuara una investigación secreta para conocer el modo de actuar de Barri, la enemistad de algunos clérigos, su por qué, y a que escuela teológica pertenecían éstos, añadiendo todas las noticias que se considerasen oportunas sobre el culto a Nuestra Señora de la Luz, como la descripción del altar o si se conocia de la existencia de alguna congregación o cofradía vinculada a dicho culto ${ }^{35}$.

El 2 de abril de 1769, segundo aniversario de la expulsión de la Compe $\sim$ ia, el obispo remitió ampliamente la información requerida ${ }^{36}$. Desmentía la existencia de partido jesuítico alguno $y$, en consecuencia, que hubiera persecución contra Barri. Era él mismo, sin queja de parte, quien había formado la sumaria contra el párroco, que era calificado de "genio díscolo", y que ya habia sido reprendido en otras ocasiones por actuaciones inadecuadas en el desempeño de su labor pastoral, que detallaba. Lo que había provocado la orden de reclusión había sido un incidente considerado grave por el obispo. Había insultado a un presbitero que había celebrado misa en el altar 
de la Madre Santísima de la Luz, acusándolo de pecador, cuando dicho culto no estaba prohibido y tenia, por el contrario, numerosas indulgencias de distintos pontífices, confirmadas en 1765 por Clemente XIII. Sobre el altar, costeado no hacía mucho por una monja del convento de la Enseñanza, reconocía que existía una imagen de San Ignacio y la frase "Ad Maiorem Dei Gloriam. Constitutiones Societatis Jesu", y que en su última visita al convento, durante la cuaresma, había preguntado a la priora quién la había ordenado poner, y ni ella ni la comunidad lo sabían - "creía que hubiese sido oficio del pintor" - , habiendo fallecido en enero de 1769 la monja a cuyas expensas se había realizado. En cualquier caso, el obispo manifestaba que había ordenado que se borrase "Constitutiones Societatis lesu". Concluía quejándose amargamente de la conducta del párroco, que calificaba de altiva y provocadora, y remitiendo la documentación del sumario, con las testificaciones de cuatro beneficiados de la parroquia de la Magdalena, su campanero $y$ de tres labradores leridanos. Todos ellos narraban incidentes sucedidos en el desempeño de la labor y descalificaban el carácter de Barri llamándole, entre otras cosas, hombre "de genio fuerte", "bullicioso y provocativo", o "altivo y expuesto a disensiones" ${ }^{\prime \prime 3}$.

Un cariz diferente tomó la investigación secreta llevada a cabo por el alcalde mayor Ramón de Lanes, un abogado leridano que había desempeñado el cargo de asesor del gobernador de la ciudad entre 1759 y 1764 , y que había sido designado teniente de corregidor el 15 de enero de $1768^{38}$. Ante él depusieron doce testigos: fray Gerónimo Puig, prior del convento de dominicos de Lérida; los presbíteros Tomás Sardá. Atanasio Corriá y Francisco Casanoves; los canónigos Gregorio Galindo y Francisco Tabau; Jaime de Gomar i Dalmaces, un caballero leridano; el notario Anselmo Puigcerver; el abogado Pedro Nicolau; el alguacil mayor de la ciudad, Salvador Benet; el campanero de la parroquia de la Magdalena y, finalmente, Gertrudis Corriá i Solanes, una vecina de 41 años. Pese a que el beneficiado Casanoves y el campanero José Falceto tenían declaración efectuada en el sumario abierto por el obispo, todos sin excepción manifestaron ante el alcalde mayor tener una muy buena opinión del párroco Barri pues, según ellos, cumplia exactamente con sus obligaciones pastorales, era tenido por sacerdote ejemplar, "de loable vida $y$ costumbres", y como "eclesiástico aplicado". Unánimemente lo consideraban víctima de una persecución tenaz por parte de aquellos que llamaban "acérrimos secuaces de la doctrima y máximas de los expulsos y promotores de la devoción de la Virgen de la Luz", y de quienes daban sus nombres. Entre ellos se encontraban los canónigos Tomás Coder, Domingo Malegat, Juan Ramón y Juan Arjol; los beneficiados Juan Vergonyós, Miguel Mases, Jacinto Gascull, Francisco Roig, Juan Trillo, Pedro Oliver, Andrés Cuberes, Juan Ortiz y Antonio Eroles, además del notario de la curia apostólica Antonio Rubiol, del que se afirmaba tenía un gran predicamento sobre el obispo. El canónigo Malegat y el citado Rubiol eran los más citados, al ser considerados como "los principales de este género de secta, de que está tan inficionada esta ciudad" ${ }^{\prime \prime 9}$, y con notable influencia sobre las monjas del convento de la Enseñanza. Rubiol tenía en él a una de sus hermanas, y el canónigo Malegat era 
director espiritual de algunas monjas, a expensas de una de las cuales y bajo la dirección del canónigo se había levantado el aitar, y se sospechaba que como prior de la Cofradía de San Pablo, estaba alentando una facción projesuítica, pues dicha cofradía "se compone y se gobierna por clérigos secuaces de la doctrina jesuitica, excluyendo a los contrarios ${ }^{140}$, y en su testimonio el presbítero Tomás Sardá iba más lejos al sospechar que se trataba de una congregación clandestina protegida por el obispo, pues decía haber visto sobre la mesa de éste dos libros en octavo titulados "Constituciones de la Cofradía de la Virgen de la Luz", e "Historia de la Virgen de la $\mathrm{Luz}^{14 \mathrm{i}}$.

Otros frecuentaban el convento, sustituyendo como confesores a los jesuitas que cumplian con anterioridad a la expulsión esa función sacramental, "conservando en ellas la pasión y memoria de sus antiguos directores ios expatriados" ${ }^{\prime 42}$. EI canónigo doctoral Tomás Coder era hermano de Francisco Coder, sacerdote de cuarto voto del colegio de Lérida, que habia sido embarcado en Salou el 1 de mayo de 1767 en la saetía "Nuestra Señora de la Cinta", y el también canónigo Arajol se había atrevido a manifestar su adhesión al partido jesuítico cuando en el sermón de la domenica de pasión, durante la cuaresma, había afirmado ante las imágenes de San Ignacio y San Francisco de Borja que flanqueaban el altar: "ésta es la luz que nos da la enseñanza. ésta es la que dieron a la puericia mestros Padres, y a sus disciulos los buenos maestros". De los restantes se aludía, además de a su adscripción projesuita, a su moral relajada. El testimonio de Gertrudis Corriá denunciaba algunos supuestos excesos durante el carnaval protagonizados por algunos eclesiásticos, pero el del alguacil mayor, Salvador Benet, era más contundente, amparado en su cargo, que le permitía contar con información privilegiada, pues "el declarante - afirmaba por razón de su oficio está bien noticioso e instruido de los procedimientos de los más de los vecinos de la ciudad, asi seculares como eclesiásticos, por las dependencias que todos los dias tiene que correr y diversidad de sujetos con quien tratar ${ }^{143}$. Avalado por esas circunstancias, le constaba que los presbíteros "secuaces de los jesuitas" llevaban una vida poco ejemplar: Francisco Roig tenía trato continuo con señoras; Pedro Oliver vivía con una mujer de mala nota, causando "escándalo en el barrio"; Andrés Cuberes era de vida relajada; y Juan Ortiz, el denunciante de Barri, que tuvo una activa participación en el último carnaval, tenía como "principal ocupación el trato con mujeres bien parecidas".

A pesar de que las acusaciones al obispo eran menos directas, quedaba de manifiesto su adscripción al bando jesuítico. Todos concidian que su ojeriza a Barri nacía de la condición tomista de éste, y que protegía y apoyaba a los suarecistas. Según el prior de los dominicos el prelado era "propenso a las cosas de los expulsos", y los restantes eclesiásticos que testificaron ante el alcalde mayor hicieron referencias a antecedentes que probaban la posición projesuítica de Macías Pedrejón, en particular a castigos que el prelado había impuesto a los tomistas, o partidarios de "la sana doctrina": denuncia a la Inquisición por proposiciones del anterior prior de los dominicos Fray José Fuster, tras su sermón de la festividad de Santo Tomás, de 
lo que fue absuelto; $y$ suspension de licencias de predicar y confesar al mencionado dominico y al sacerdote Tomás Cerdá, por oponerse éste último al culto de la Madre Santísima de la Luz. Los también testigos en el sumario abierto por el obispo - el campanero Falceto y el presbítero Casanoves - señalaron el interés del obispo porque declarasen faltas cometidas con Barri en el ejercicio de su labor pastoral. Según el campanero, "el Sr. Obispo estaba ansioso de encontrar delito en el cura" Casanoves también percibió un afán exagerado en el prelado cuando le preguntó el 13 de febrero sobre la conducta de Barri. El notario Anselmo Puigcerver, con poderes de Barri para gestionar su libertad cuando fue recluido en el convento de los Capuchinos. denunció los ardides formales que el obispo había utilizado para evitar recibir el memorial y el requerimiento por él redactados solicitando la libertad del párroco ${ }^{45}$. Como es de apreciar, la forma de efectuar la pesquisa y de seleccionar los testigos por Ramón de Lanes mostraba bien a las claras que estaba realizada con la intención premeditada de exculpar a Barri y de implicar a sus oponentes.

El segundo núcleo de la investigación secreta del alcalde mayor se refería al altar de la Madre Santísima de la Luz, y a la actitud de las monjas del Convento de la Enseñanza. Las descripciones del altar eran todas coincidentes, destacando la proliferación de motivos jesuíticos: en uno de sus ángulos se apreciaba una cesta llena de corazones y, además de las imágenes de San Ignacio y San Francisco de Borja, con las inscripciones ya referidas de A.M.D.G. y Constitutionis Societatis Jesu. las armas de la Compañía - IHS - aparecían al pie del cuadro, en la custodia que sostenía en su mano izquierda San Ignacio, y en la ostia que emergía del cáliz que sostenía San Francisco de Borja. Según el canónigo Galindo, el cuadro procedía de un coadjutor jesuita de Zaragoza, que lo envío a Lérida para que formara parte de un nuevo altar a levantar en el Convento o, en su defecto, en el propio Colegio de la Compañía, y fue después de la expulsión cuando una de las hermanas, Juana Castillo, "de las más apasionadas de los expulsos", construyó el altar a sus expensas. sustituyendo un cuadro de la Asunción, bajo la dirección de su director espiritual el canónigo Malegat ${ }^{40}$. Gran parte de los testimonios ponian énfasis en que el aitar se habia convertido en un símbolo que conservaba la memoria de los expulsos, y que mantenía la cohesión de sus partidarios y, al igual que Barri, consideraban que el culto a la Madre Santísima de la Luz estaba incluido en la prohibición de Benedicto XIV al culto de la Madona dei Lumen que se extendió por el reino de Nápoles en la década de los treinta. Según el canónigo Galindo, la existencia del altar era una contravención a los decretos pontificios, y "una desaprobación, y aún falta de respeto, a las providencias tan venerables del Monarca", y causa de disensiones entre los fieles leridanos, unos partidarios de sostenerlo, otros desaprobando que se utilizara para el culto ${ }^{47}$.

Por último, existía preocupación por lograr que las monjas del Convento de la Enseñanza se vieran libres de la influencia jesuitica que les llegaba por el trato asiduo en el locutorio o en el confesionario con la facción denunciada de projesuita. que las mantenían en la ignorancia sobre las causas de la expulsión, sin permitirles 
leer las pastorales de diversos prelados contra la Compañia ${ }^{48}$. El obispo Climent había tenido que actuar en su diocesis con mano firme, separando al confesor del monaterio de la Enseñanza de Barcelona y enfrentándose con su priora, Francisca Moner ${ }^{44}$.

La orden habia tenido tradicionalmente una fuerte vinculación con la Compañía de Jesús. Su fundadora. Juana de Lestonnac, había encontrado en San Ignacio su fuente de inspiración, y en miembros relevantes de la Compañía, como Ios padres Bordes y Raymont, o el cardenal Roberto Belarmino, el apoyo imprescindible para que en 1607 el papa Paulo V confirmara y aprobara la fundación $^{30}$. La primera casa fundada en España fue la de Barcelona en $1650^{51}$, y al inicio de la década de 1760 funcionaban, además de las de Barcelona y Lérida. casas de enseñanza en Tudela, Tarragona, Zaragoza, Urgel y en la ciudad de Mejjico, donde en 175 I existían dos altares con imágenes de la Madre Santísima de la Luz en colegios de la Compañía: uno, en el Colegio Máximo de San Pedro y San Pablo, y otro en el Colegio de San Andrés. No es inusual encontrar textos de padres de la Compañia de Jesús destacando el carácter jesuitico de una orden femenina que, si bien conocida comunmente como de la Enseñanza, tenia como nombre fundacional el de Compañía de María Nuestra Señora. Francisco Javier Lazcano, sacerdote del Colegio Máximo de San Pedro y San Pablo de Méjico, las llegaba a considerar una rama femenina de la orden ignaciana cuando afirmaba que "ha de blasonar la Compañia de Maria de un congenial hermandad con la Compañia de Jesús", para añadir poco después en referencia a la religiosas, "siendo juntamente esposas, madres y hermanas uterinas de la Compañia, profesando el Instituto mismo y Regla de los Jesuitas ${ }^{152}$, y de la misma opinión era el P. Bernardo Pazuengos, Procurador General de la Provincia de Filipinas y rector del Colegio de San Ignacio de Manila en el momento del extrañamiento ${ }^{53}$, quien afirmaba, en 1755 , que "conformando el Instituto de la Compañia de Jesús con la de María, que están en el mismo, como es la misma Doctrina de la Madre, y la del Hijo, sólo con la diferencia de los ministerios discretisimamente acomodados al respectivo sexo" ${ }^{54}$. Era cierta, pues, la declaración del canónigo Galindo que afirmaba haber leido en una historia de la orden, que sus reglas o constituciones estaban inspiradas en las de San Ignacio, y que su modelo era el de la Compañia. Eran fundadas las sospechas de que en el convento se seguían leyendo apologias sobre los jesuitas, y que sólo eliminando el altar, "nocivo a las religiosas y su retiro", y prohibiendo la presencia en el convento de los partidarios de la Compañía, se podría desarraigar del convento el espiritu jesuitico, muy firmemente asentado, pues en certificaciones que la fïscalía del Consejo de Castilla solicitó a la Secretaría de Cámara del obispo, pudo saberse que la última festividad de San Ignacio se celebró en el convento "con completas, con música, se tiraron algunos truenos y se cantó la misa con la música de la Cathedral"1.5.

El dictamen redactado por el fiscal Moñino el 18 de diciembre de 1769, si bien cuidadoso en las formas con el obispo leridano, lo desautorizaba plenamente en el fondo de su contencioso con Domingo Barri. Ningủn asunto de gravedad, según el fiscal, justificaba el castigo impuesto al párroco de la Magdalena, pues todo "está 
reducido a varias indescreciones o ligerezas cometidas en su oficio" y, por tanto, el caso debía quedar sobreseido. Le parecía inadecuado que se permitiera el culto a la Madre Santísima de la Luz, por su evidente similitud con la Madona dei Lumen, prohibido por la Sagrada Congregación de Ritos durante el pontificado de Benedicto XIV, resultándole extraño a Moñino que el obispo "carezca de las ciertas noticias que hay sobre este punto que convencen como verdadera la prohibición de que se ha hablado"sh , además de su vinculación con la Compañia, pues fueron jesuitas quienes llevaron la pintura, los que facilitaron su colocación en el convento, y contaron con el apoyo entusiasta de las monjas. Para dar una pequeña satisfacción al prelado, Moñino echaba de menos en Barri una mayor "prudencia, discreción y cautela" en su comportamiento, y que era conveniente una mejor armonía con su ordinario. Sus conclusiones eran: dar por terminado el asunto; sugerir al prelado que retirase del altar toda la parafernalia jesuítica, "para desterrar todo motivo a ilusiones, supersticiones y engaños (...) que sólo pueden servir en el dia de recuerdo inútil y de preocupación en las monjas y otros algunos que se reconocen adictos a los regulares expulsos"; y, finalmente, evitar que los partidarios de los jesuitas tuvieran comunicación con las monjas: "que inicamente asistan a las religiosas en todas sus necesidades aquellos ministros que estén libres de toda siniestra preocupación". El auto del Consejo Extraordinario de 4 de febrero de 1770 recogia esencialmente el dictamen de su fiscal: Barri volvía a su curato tras el sobreseimiento de su causa por el obispo; presentación de aquél ante su prelado para mostrarle subordinación, evitando discordias en lo sucesivo; eliminación del altar y de los símbolos jesuíticos y de aquellos elementos que motivaron la prohibición papal; y apartar a las monjas de los eclesiásticos considerados projesuitas ${ }^{57}$.

Sólo faltaba el acuse de recibo del prelado, lo que tuvo lugar el 22 de febrero. Obedecía en todo al auto de 4 de dicho mes, pero no dejaba de lamentar la desconfianza manifestada hacia él por el Consejo: "debo hacer presente al Consejo que me sirve de grande confusión que pueda haber queja en el manejo y celo pastoral que me incumbe para el arreglo y dirección de esta comunidad"s. Una desconfianza que se mantendría incólume, pese a la nube de certificados que el obispo remitió al Consejo sobre las provisiones por él tomadas en relación a la vida conventual de la Enseñanza, y el edicto episcopal que firmó el 16 de marzo de 1770 ordenando a todos los religiosos sacar de iglesias y capillas, tanto públicas como privadas, las imágenes de la Madre Santísima de la Luz, y "a todos los fieles de ambos sexos que no las veneren pública ni privadamente en qualquiera modo que estén. ya sea de bulto, de pintura, en papel, lienzo o grabadas en medallas de qualquiera metal que sea."

Los sucesos de Lérida dieron lugar a un edicto del arzobispo de Zaragoza, Juan Saenz de Buruaga, fechado el 10 de mayo de $1770^{\circ /}$, justificado por su deber de velar por el uso legítimo de las imágenes sagradas y evitar la propagación de falsas revelaciones y milagros. Pese a estar prohibidos por la Congregación de Ritos la devoción a la Madre Santísima de la Luz y los escritos que la promovían, el 
prelado zaragozano denunciaba su gran difusión "no se por qué espiritu de singularidad". El edicto ordenaba eliminar las imágenes existentes, tanto públicas como privadas, y su entrega a los párrocos, así como la prohibición de cofradías, libros, novenas y devocionarios referentes a su culto.

Una providencia del Consejo Extraordinario, fechada el 9 de junio de 1770, recogía la iniciativa del arzobispo zaragozano, y se disponía a erradicar completamente de España cualquier vestigio de la devoción a la Madre Santísima de la Luz, en particular en aquellos conventos de religiosas que habían tenido a jesuitas como directores espirituales. Según el Consejo, su imagen "puede persuadir, o inducir a creer, que saca un condenado de las llamas del Infierno y boca del Dragón, y no precisamente que le preserva, cuya alusión en aquél sentido se opondría inmediatamente al Dogma Católico"61. Se ordenaba, así mismo, que los obispos españoles publicaran edictos del mismo tenor que el del arzobispo Saenz de Buruaga, y se daba instrucciones a las Chancillerias y Audiencias para que recogiesen el material propagandístico relacionado con el caso, como libros, estampas o medallas. Además, se incitaba a los prelados que vigilaran especialmente aquellos conventos de religiosas que hubieran estado, de alguna manera, en relación con padres de la Compañía, instruyendo a las prioras, amonestándolas o, en casos extremos, mediante apremios legales, "zelando mucho que las niñas jóvenes educadas no se imbuyan de especies contrarias al Govierno, ni se exciten devociones que no estén legitimamente aprobadas".

Desconocemos el grado de cumplimiento de la providencia del Consejo, aunque presumimos que sería absoluto. En algunos casos de prelados celosos en el cumplimiento de los dictados de la Corte, el edicto fue acompañado de una pastoral, como sucede con el ya señalado de Fray Francisco Armañá. Desde luego, la Audiencia de Aragón dictó una orden el 6 de julio de 1770, por la que otorgaba un plazo de cuatro dias para que los vecinos entregaran en aquel tribunal todo aquello que hubiera servido para divulgar la devoción, y en especial láminas o planchas originales que sirvieran para estampar la imagen ${ }^{62}$.

Tenemos constancia de que el prelado leridano, Macías Pedrejón, cumplió en junio de 1770 con la providencia del Consejo. El 21 de dicho mes hizo público un edicto que mandaba, bajo pena de excomunión, la entrega de todos los libros, novenarios, devocionarios y papeles destinados a promover el culto de la Madre Santísima de la Luz, que quedó tan proscrito en España como la orden religiosa que lo había alentado y cuya extinción se solicitaba a Roma con creciente insistencia, incluso con el apoyo sin reservas del propio obispo leridano. Solicitado por el gobierno en el otoño de 1769 para que emitiera su parecer sobre la conveniencia de borrar la Compañía de Jesús de la faz de la Iglesia ${ }_{63}$, no dudó - como tantos otros prelados - en dar pruebas inequívocas de su sumisión al monarca, manifestando un ferviente regalismo, y declarando un despego antiguo hacia los jesuitas y su entorno. Tras afirmar que "tuve poquísimo trato" con los padres de la Compañía, y no 
recordar haber asistido a su Colegio e Iglesia - "aunque he asistido a funciones en iglesias de otras comunidades, no hago memoria de aver asistido alguna vez en la suya, ni entré en su Colegio sino muy rara", decía Macías Pedrejón - finalizaba declarándose favorable a la extinción sin paliativos : "juzgo preciso el recurso hecho a Su Santidad para su absoluta extinción y necesaria su instancia" ${ }_{64}$. 


\section{NOTAS}

1.- A.G.S. Gracia y Justicia, leg. 667. Consejo Extraordinario. Madrid, 30 de abril de 1767.

2.- Las polemicas sobre el culto al Corazón de Jesús en el siglo XVIII se encuentran brillantemente sintetizadas en Antonio MESTRE SANCHIS: La Iglesia en la España de los siglos XVII y XVHI, vol. IV de la Historia de la Iglesia en España Madrid 1979, pp. 660-664.

3.- En la introducción al libro de Lucas RINCÓN S.l.: Antidoto contra todo mat, Méjico 1737-1738. se dice que la Virgen eligió Sicilia para su primera aparición como Nuestra Señora de la Luz "porque precederia alli la antigua costumbre de saludar a Nuestra Señora en la Letania Lauretana diciéndoia: "Sancta Maria Mater Luminis. Ora pro nobis".

4.- Dicgo de RIVERA: Sermón de la Madre Santissma de la Luz, Madrid, 1756, pp. I1-12. Debo agradecer al Dr. D. Francisco Fernández Izquierdo que me facilitara una copia del ejemplar conservado en la Colección Cervantes del Instituto de Filologia del C.S.I.C. La virgen de la Luz a la que hacemos referencia nada tiene que ver con su omónima que se venera en el archipiélago canario. o en ouras poblaciones de la Peninula, como Cuenca. En el siglo XVI esa advocación era frecuente en parroquias de Tenerife o la Palma. Cfr. Juan B. LORENZO RODRIGUEZ: Noticias para la Historia de La Palma, La Laguna 1975, tomo I, p. 177. Los promotores jesuitas del culto no dejaban de distinguirlo de otros similares: "aunque se han hecho exactas diligencias a fin de averiguar si en otra parte havia alguma imagen en que la Gran Señora fuesse venerada con el mismo titulo, no se ha hallado, aunque sícon el de Nuestra Señora de la Luz. u otros semejantes a éste, y distintos del de Madre Santissima de la Luz". en José TOBAR: La invocación..., pp. 22-23.

5.- José de TOBAR: La mocación de Nuestra Señora con el tituio de Madres Santissima de la Luz Madrid. 1751 , p. 34.

6.- Diego de RIVERA: Sermon de la Madre Santíssima de la Luz, que en el dia de su colocacion en el precioso altar, y adorno, que ie renia preparado la devoción de sus congregantes en la iglesia del Colegio Imperial de la Compañia de Jesis, Madrid, 1756, $22 \mathrm{pp}$.

7.- José SIMÓN DIAZ: Historia del Colegio Imperial de Madrid, $2^{a}$ edición actualizada. Madrid 1992 , pp. 84-85.

8. Fue publicada por la Imprenta de la viuda de Miguel de Peralta, de Madrid. y contaba con la aprobación de Bonifacio Frías, abadiano de la Congregación del Oratorio de San Felipe Neri, y la cel jesuita P. Ignacio Guerrero.

9.- La relación de milagros y prodigios ocupa de la pág. 76 a la 100.

10.- "...hacia esto Oliva, rogando al Señor diesse salud a su hijo, aunque le volviese a elita su antigua enfermedad, y haviendo entre las súplicas quedado dormida, oyó en sueños como una voz que le decia: alegrale. Oliva, tendras seguramente ia gracia: ves ay a si Siervo Ignacio para hacértela sin dilación; y en aquél punto se le represento San Ignacio de Loyola. que mirándola con ojos amorosos la dijo: consuelate y ten fe en la Madre Santissima de la Luz, que te quiere atender", en Jose TOBAR: La invocación..., pp. 96-97.

11.- José de TOBAR: La invocación..., p. 78. 
12.- Fue impreso en la imprenta de José Sort.

13.- Cita recogida por Tobar del capt. I, part. I, del tomo I de la edición palermitana de 1733 de La devoción de Maria, Madre Santisima de la Luz. Cfr. TOBAR, p. 21.

14.- Archivio Secreto Vaticano (A.S.V.) Nunciatura de Madrid, Leg. 138.

15.- A.S.V. Nunciatura de Madrid, Leg. 138.

16.- La respuesta del Obispo palentino Bustamante fue negativa "respondió que no solamente no podia permitir se hiciese la función prevenida, pero que aún poner en parte pública la pintura traida de Roma, y que la otra que tenia puesta al lado del balcón de su casa el referido D. Manuel con todos los exvotos de cera y lámpara lo hiciese quitar en el dia", en A.S.V. Nunciatura de Madrid, Leg. 138.

17.- El nombre de monjas de la Enseñanza respondía a la denominación común que en España recibia la orden religiosa de la Compañía de María Nuestra Señora, fundada en Francia a principios del siglo XVII y primera Orden religiosa femenina de enseñanza.

18.- Diego de RIVERA: Op. cit. p. 14.

19.- José de TOBAR: La invocación..., p. 7.

20.- Diego de RIVERA: Sermón de la Madre Santíssima de la Luz, Madrid, 1756, p. 4. Según la edición parmelitana de La devoción de Maria. Madre Santíssima de la Luz, fechada en 1733, y transcrita por Tobar, fue la propia Virgen la que dirigió la mano del pintor. Dirigiéndose a la dama en una segunda aparición la Virgen le ordenó: "Vete al pintor, que está actualmente con la obra entre manos: allá me hallarás, a ti sóla visible; y entretanto que tü, teniéndome delante de los ojos. instruyeres con la voz al pintor, yo invisiblemente le dirigiré el pincel, de modo, que acabada la obra, qualquiera conocerá de su belleza más que humana", en José TOBAR: La invocación..., p. 18.

21.- El manto azul era frecuente en la pintura mariana. En 1649, Francisco Pacheco en su Arte de la Pintura señalaba que debía llevar siempre puesto un manto azul, por ser el azul el color del espacio, la luz y la eternidad, del mar y del cielo.

22.- José de TOBAR: Invocación..., Madrid 1751, p. 10.

23.- A.S.V. Nunciatura de Madrid, Leg. 138

24.- Mientras que en la traducción del texto italiano, editado en Palermo en 1733, se lee "sacar del horrible abysmo del Infierno una alma pecadora", José Tobar habla de "el garboso ademán con que retira aquella alma de su peligro, y para que no cayga la sugeta con aquella mano, con que ojalá nos sujete a todos", en José TOBAR: La invocación..., pp. 24-25.

25.- Marina WARNER: Tú sola entre las mujeres. El mito y el culto de la Virgen María. Madrid, 1991, pp. 413-427.

26.- Francisco ARMAÑA: "Pastoral III del culto que se debe a las Sagradas Imágenes, y prohibición de las que se publicaron con el título de Nuestra Señora de la Luz", en Pastorales del Ilmo. Sr. D. Fr. I I, Obispo que fue de Lugo, actual Arzobispo de Tarragona, Tarragona 1794, Tomo 1, pp. 269-309 (la cita corresponde a pp. 306-307).

27.- Ibidem. p. 307. 
28.- Veánse los interrogatorios al Canónigo Berga de Gerona y sus declaraciones en la pesquisa reservada contra los miembros del cabildo filojesuitas, estudiada por Teófanes Egido. El furor vengativo de Berga y su resentimiento nos recuerda al de Barri. Cfr. Teófanes EGIDO e Isidoro PINEDO: Las causas "gravisimas" y secretas de la expulsión de los Jesuitas por Carlos III, Madrid 1994, pp. 69-70.

29.- Según testimonio de Jaime de Gomar y de Dalmases, una caballero de Lérida, Barri no pudo iniciar la docencia en el Seminario "por los influjos de los Regulares expulsos, y a fin de que éstos tuvieran mayor numero de estudiantes en el curso que empezaron aquel año en su Colegio", en A.H.N. Clero. Jesuitas, Leg. 780, Testimonio de jaime de Gomar y de Dalmases 11 de abril de 1769. Tras la expulsión de los jesuitas, y pese a las disposiciones del gobierno en contrario, en el Seminario se siguió estudiando moral por la Summa del P. Larraga, y sin preceptor, como denunciaba en su testimonio el dominico fray Gerónimo Puig.

30.- Ramón CORTS I BLAY: L'arquebisbe Fèlix Amat (1750-1824) i l'última Il.lustració espanyola, Barcelona 1992, pp. 33-34.

31.- A.H.N. Clero. Jesuitas, Leg. 780; Domingo Agustín Barri a Pedro R. de Campomanes, Lérida, 13 de septiembre de 1767.

32.- Enrique de Wyels ocupó interinamente el cargo de gobernador entre la muerte del mariscal de campo Francisco Crespo Ortiz, acaccida el 11 de agosto de 1767, y la toma de posesión del también mariscal de campo Diego Oxburg, que no tomó posesión hasta el 11 de abril de 1768.

33.- A.H.N. Ibidem. Leg. 780 Enrique de Wyels a José Moñino, Lérida, 27 de marzo de 1768.

34.- A.H.N. Ibídem. Leg. 780 Memorial de Domingo Agustín Barri al Fiscal del Consejo Pedro Rodriguez de Campomanes, Lérida, 3 de marzo de 1768.

35.- A.H.N. Ibidem. Dictamen Fiscal, Madrid, 15 de marzo de 1769.

36.- A.H.N. Ibídem. Leg. 728 Manuel, Obispo de Lérida, a José Moñino, Lérida, 2 de abril de 1769.

37.- A.H.N. Ibidem. Leg. 780 Sumaria información de testigos recibida contra D. Domingo Barri.

38.- A.G.S. Gracia y Justicia, libro 1.573, y en Gaceta de Madrid, 26 de enero de 1768, p. 32. Tras su primer destino en Lérida, la carrera de Lanes progresó: en 1772 pasó a la alcaldía mayor de Tortosa, en 1777 a la de Daroca, alcanzando el corregimiento de Onteniente en julio de 1782.

39.- A.H.N. Ibídem. Leg. 780: Testimonio de Anselmo Puigcerber, notario real Lérida, 15 de mayo de 1769.

40.- A.H.N. Ibiden. Leg. 728 Testimonio del Dr. D. Gregorio Galindo, canónigo de la Santa Iglesia de Lérida Lérida, 9 de mayo de 1769. La cofradía estaba destinada a la enseñanza de la doctrina cristiana, pero según el prior de los docminicos, todos los que concurrían "son secuaces de la doctrina jesuitica".

41.- A.H.N. Ibidem. Leg. 748, Testimonio del presbitero Tomás Sardá, Lérida, 15 de mayo de 1769.

42.- A.H.N. Ibidem. Leg. 780 Testimonio del prebitero Tomás Sardá, Lérida, 17 de mayo de 1769.

43.- A.H.N. Ibídem. Leg. 748 Testimonio de Salvador Benet, alguacil mayor de Lérida, Lérida, 16 de mayo de 1769 . 
44.- A.H.N. Ihidem. Leg. 748 Testimonio de José Falceto, campanero de la Iglesia de la Magdalena. Lérida, 15 de mayo de 1769 .

45.- El Obispo alegó para negarse a recibir los escritos del notario Puigcerver que sólo admitiria documentos presentados por el escribano de su Curia Eclesiástica.

46.- A.H.N. Ibidem. Leg. 748 Testimonio del Dr. D. Gregorio Galindo. canóngo de la Santa Iglesia de Lérida, Lérida, 9 de mayo de 1769.

47.- Sobre la disensiones entre los vecinos, y el temor a disturbios por esa causa se manifestaron el caballero Jaime de Gomar y Dalmases, el presbitero Anastasio Corria, y el ya citado canónigo Gregorio Galindo.

48.- Contaba el canonigo Galindo que en una ocasión dió a leer a una de las monjas de la congregacion un escrito de Palafox: "solo ella la leyó, y esto ocultamente por el temor a las demás religiosas, y que una que le vio el libro alguna vez en las manos, preguntándole si aquel libro del señor Palafox hablaba contra jesuitas, y respondiole que si pero que decia la verdad. bastó ésto para no leer ni una palabra", en A.H.N. Jbidem. Leg. 748 Testimonio del Dr. D. Gregorio Galindo, canónigo de la Santa igiesia de Lérida, Lérida, 9 de mayo de 1769.

49. - Francesc TORT MITJANS: El obispo de Barcelona Josep Climen i Avinent (1706-1781), Barcelona, 1978, p.305.

50.- Isabel AZCARATE RISTORI: El origen de las Ordenes femeninas de enseñanza y la Compañia de Maria, San Sebastián, 1963, pp. 43 y ss.

51.- Francesc TORT MITJANS: Op. Cit., p. 304.

52.- Parecer del P. Francisco Xavier Lazcano. Religioso de la Compañia de Jesüs al Sermón que en la erección de su primer convento y templo dedicado a Nra. Sra. del Pilar en la ciudad de México predicó el P. Bernardo Pazuengos, Méjico, 1755.

53.- Pazuengos era natural de Guernica, donde habia nacido el 22 de mayo de 1706. Ingreso en la Compañia el 9 de octubre de 1720, profesando de cuarto voto el 15 de agosto de 1739. Se hallaba en Filipinas desde 1732. Extrañado de Manila el 23 de enero de 1770 , residió en la legación Ferrara, falleciendo en Bagnacavallo el 6 de septiembre de 1773, en A.G.S. Dirección Generai del Tesoro Inventario 27, Leg. 12.

54.- Bernando PAZUENGOS S.I: Maria Santíssima, dechado de religiosas de su Compañia. llamadas comunmente de la Enseñanza, México, 1755.

55.- A.H.N. Ibidem. Leg. 748 Cerfificaciones de D. Agustin Saban. Secretario de Cámara del obispo de Lérida, Lérida, 18 de febrero de 1770.

56.- A.H.N. Ibidem. Leg. 748 Dictamen del Fiscal José Moñino, Madrid, 18 de diciembre de 1769.

57.- A.H.N. Ibidem. Leg. 748 Auto del Consejo Extraordinario, Madrid, 4 de febrero de 1770.

58.- A.llN. Ibidem. Leg, 748 Mamuel, Obispo de Lérida, a Pedro R. de Campomanes, Lerida, 22 de febrero de 1770 .

59.- A.S.V. Nunciatura de Madrid, Leg. 138, ff. 138-138v. 
60.- A.S.V. Nuncianura de Madrid, Leg. 138, ff. 139-140v.

61.- A.S.V. Nuncianura de Madrid, Leg. 153, f. 68.

62.- A.S.V. Nunciatura de Madrid, L.eg. 138.

63.- Un análisis global de los dictámenes de los obispos, en Teófanes EGIDO: "Actitudes regalistas de los obispos de Carlos III", en Estado y Fiscalidad en el Antiguo Régimen, Murcia 1989, pp. 67-83.

64.- A.G.S. Gracia y Justicia, Leg. 688 Manuel, Obispo de Lérida a Roda, Lérida, 17 de septiembre de 1769. 